\title{
Smoking cessation affects the natural history of COPD
}

\author{
This article was published in the following Dove Press journal: \\ International Journal of COPD \\ 16 November 2017 \\ Number of times this article has been viewed
}

Jiu-Wu Bai'

Xiao-xin $\mathrm{Chen}^{2}$

Shengsheng Liu $^{3}$

Li Yu'

Jin-Fu $X u^{\prime}$

'Department of Respiratory and Critical Care Medicine, Shanghai

Pulmonary Hospital, Tongji University

School of Medicine, Shanghai,

${ }^{2}$ Department of Respiratory

Medicine, Second Peoples Hospital of

Nantong, Nantong, Jiangsu Province,

${ }^{3}$ Department of Tuberculosis, Anhui

Chest Hospital, Hefei, Anhui Province,

People's Republic of China
Correspondence: Jin-Fu Xu

Department of Respiratory and Critical

Care Medicine, Shanghai Pulmonary

Hospital, Tongji University School of

Medicine, 507 Zhengmin Road, Shanghai,

200433, People's Republic of China

Tel +8621 65II 5006

Fax +86 21 55663299

Email jfxucn@gmail.com
Background: Cigarette smoking is the most commonly encountered and readily identifiable risk factor for COPD. However, it is not clear which quantitative factors related to smoking influence the prognosis of COPD patients.

Methods: A total of 204 patients with a long-term history of smoking were enrolled into this study and followed up for 5 years. Patients were divided into "death" or "survival" groups based on follow-up results and "quitting-smoking" or "continuing-smoking" groups based on whether they gave up smoking.

Results: Patients in the death group had a longer smoking time, lower prevalence of quitting smoking, later onset of COPD symptoms, older age at quitting smoking, lower forced expiratory volume in one second $\left(\mathrm{FEV}_{1}\right) \%$ predicted, and lower ratio of $\mathrm{FEV}_{1} /$ forced vital capacity. Age, age at quitting smoking, and $\mathrm{FEV}_{1} \%$ predicted were independently associated with mortality from COPD. Compared to the continuing-smoking group, the quitting-smoking group had a lower mortality rate, longer course of COPD, earlier onset of COPD symptoms, and lower residual volume percent predicted. During the 5-year follow-up, 113 deaths were recorded (quittingsmoking group: $n=92 ; 40$ deaths; continuing-smoking group: $n=112 ; 73$ deaths). The mortality risk remained significantly higher in the continuing-smoking group than the quitting-smoking group (log-rank test, $13.59 ; P=0.0002$ ).

Conclusion: Smoking time may be related to the mortality rate from COPD. Smoking cessation has the greatest capacity to influence the natural history of COPD.

Keywords: chronic obstructive pulmonary disease, cigarette smoking, smoking cessation

\section{Introduction}

COPD is a major cause of chronic morbidity/mortality and is the fourth leading cause of death all over the world. ${ }^{1}$ COPD is characterized by a persistent limitation of airflow caused by chronic inflammatory responses to noxious particles or gases. Cigarette smoking is the most commonly encountered and readily identifiable risk factor for COPD ${ }^{2}$ which progresses in $\approx 15 \%$ of smokers. ${ }^{3}$ COPD is $3-5$ times more likely to occur in smokers than in nonsmokers. ${ }^{4}$

Cigarette smoke contains $\approx 4,700$ chemical constituents and can increase production of endogenous reactive oxygen species in target cell populations. ${ }^{5,6}$ However, the underlying molecular mechanisms for the significant variability in developing COPD in response to cigarette smoking are incompletely understood. Cigarette smoking can result in abnormal pulmonary inflammation, whereby neutrophils, macrophages, and lymphocytes infiltrate lung tissue. ${ }^{7}$ These cells release proinflammatory mediators. A complex network of inflammation comprising various inflammatory cells and mediators can lead to damage to the pulmonary architecture. Oxidation/antioxidant imbalance, protease/anti-protease imbalance, dysfunction of the autonomic nervous 
system, and changes in cholinergic nerves further aggravate the pulmonary inflammation and limited airflow wrought by COPD.$^{8-10}$ Continuation of cigarette smoking associated with increased oxidative stress can result in frequent hospitalization and reduced quality of life.

It is not clear which factors (eg, amount of smoking, number of cigarettes smoked in one day, age of onset of smoking, smoking time, and time and age of quitting smoking) influence the prognosis of COPD patients. We explored the correlation between these factors and the prognosis of COPD patients.

\section{Methods}

\section{Study participants}

Written informed consent was obtained from all patients. The study protocol was approved by the Ethics Committee of Shanghai Pulmonary Hospital (K17-002; Shanghai, People's Republic of China). The study was carried out in accordance with relevant guidelines and regulations.

We retrospectively collected data from 526 consecutive inpatients diagnosed with COPD in the Shanghai Pulmonary Hospital between January 2009 and September 2011. We identified 245 patients who had a long-term smoking history ( $\geq 10$ pack-years) and were diagnosed with COPD.

Of those 245 patients, 41 were lost to follow-up. The remaining 204 patients were recruited for this study and followed up during the subsequent 5 years. Patients were divided into the "death" group and "survival" group based on follow-up results, and "quitting-smoking" group and "continuingsmoking" group based on whether they gave up smoking. Patients who had given up smoking for $>1$ year were adopted into the quitting-smoking group, whereas the remainder were adopted into the continuing-smoking group.

\section{Diagnosis of COPD}

The inclusion criteria for COPD were the measurement of a postbronchodilator forced expiratory volume in one second/ forced vital capacity $\left(\mathrm{FEV}_{1} / \mathrm{FVC}\right)<70 \%$ and a history of exposure to risk factors for COPD (smokers with $\geq 10$ pack-years). These criteria are in accordance with the criteria published by the Global Initiative for Chronic Obstructive Lung Disease. ${ }^{1}$

\section{Interview questionnaire and blood samples}

The interview questionnaire included questions on the following topics: general and anthropometric information (ie, age and sex); amount of smoking (pack-years smoked, where the smoking Index was defined as the number of packs smoked per day multiplied by the number of years smoked); number of cigarettes smoked in 1 day; age of onset of smoking; smoking time (years from starting to quitting smoking, follow-up, or death); age at which smoking ceased; time of smoking cessation (number of years from quitting smoking to follow-up or death).

\section{Lung function}

Pulmonary function tests were conducted for each patient during the stable phase of COPD. Data collected included FVC $\%$ predicted, $\mathrm{FEV}_{1} \%$ predicted, $\mathrm{FEV}_{1} / \mathrm{FVC}$, residual volume $(\mathrm{RV}) \%$ predicted, the ratio of $\mathrm{RV}$ to total lung capacity, single-breath diffusing capacity of carbon monoxide $\%$ predicted, and airway resistance $(\mathrm{R}) \%$ predicted. The partial pressures of oxygen and carbon dioxide were also assessed.

\section{Survival analyses}

All patients were asked routinely to sign a consent form upon hospital admission that authorized follow-up every 3 months through telephone or face-to-face interviews. Follow-up was completed on December 31, 2016. A patient was considered "lost to follow-up" if we were unable to contact him/her for each follow-up session during the study period. The study endpoint was all-cause mortality. Information regarding the cause and date of death was obtained from hospital medical records for patients who died within the hospital and from official death certificates in other situations. The causes of death were also analyzed in smoking-cessation group and continuing-smoking group.

\section{Statistical analyses}

SPSS v19.0 (IBM, Armonk, NY, USA) was used for statistical analyses. Data are as mean and standard deviation for quantitative variables and as absolute numbers and percentages for qualitative variables.

The Kolmogorov-Smirnov test was used to analyze the distribution of variables. In the bivariate analysis, the Student's $t$-test for independent variables was used to analyze normally distributed variables, and the Mann-Whitney $U$-test was used to analyze variables with a nonnormal distribution. Qualitative variables were compared using the $\chi^{2}$ test.

A Cox proportional hazard regression model was used to assess the factors associated with survival. Variables that presented significant differences $(P<0.05)$ in the bivariate analysis and were of clinical interest were included as independent variables. The dependent variables were COPD and 
all-cause mortality. Survival curves for the two main groups (quitting-smoking and continuing-smoking) were constructed according to the Kaplan-Meier method and compared using the log-rank test. Hazard ratios and 95\% confidence intervals for independent variables were also calculated.

\section{Results}

The different characteristics of the death group and survival group are shown in Table 1. There were no significant differences between them in terms of the sex ratio, amount of smoking, number of cigarettes smoked in 1 day, or the time of quitting smoking. The ages of patients in the death group were greater than those in the survival group. Death-group patients had longer smoking times, a lower prevalence of quitting smoking, later onset of COPD symptoms, and an

Table I Clinical characteristics of patients in the death group and survival group

\begin{tabular}{|c|c|c|c|c|}
\hline Parameter & $\begin{array}{l}\text { Both } \\
\text { groups }\end{array}$ & $\begin{array}{l}\text { Death } \\
\text { group }\end{array}$ & $\begin{array}{l}\text { Survival } \\
\text { group }\end{array}$ & $P$-value \\
\hline Subjects, $n$ & 204 & 113 & 91 & \\
\hline $\operatorname{Sex}(M / F), n$ & $201 / 3$ & $110 / 3$ & $91 / 0$ & 0.083 \\
\hline Age, years & $67.9 \pm 9.4$ & $71.0 \pm 8.5$ & $64.0 \pm 8.9$ & $<0.00$ I \\
\hline Pack-year & $45.3 \pm 34.5$ & $45.1 \pm 36.5$ & $45.7 \pm 32.0$ & 0.897 \\
\hline Smoking time, years & $38.2 \pm 11.5$ & $40.3 \pm 12.7$ & $35.7 \pm 9.3$ & 0.003 \\
\hline $\begin{array}{l}\text { Cigarettes smoked } \\
\text { in I day, n }\end{array}$ & $23.0 \pm 13.0$ & $22.5 \pm 14.0$ & $23.6 \pm 11.6$ & 0.539 \\
\hline $\begin{array}{l}\text { Age of onset of } \\
\text { smoking, years }\end{array}$ & $25.9 \pm 8.3$ & $27.0 \pm 8.8$ & $25.7 \pm 7.4$ & 0.059 \\
\hline Quitting smoking & 92 & 40 & 52 & 0.001 \\
\hline $\begin{array}{l}\text { Time of quitting } \\
\text { smoking, years }\end{array}$ & $4.4 \pm 7.0$ & $3.6 \pm 6.4$ & $5.3 \pm 7.7$ & 0.083 \\
\hline $\begin{array}{l}\text { Age of quitting } \\
\text { smoking, years }\end{array}$ & $58.8 \pm 10.4$ & $62.8 \pm 10.8$ & $55.6 \pm 8.9$ & 0.001 \\
\hline $\begin{array}{l}\text { Course of disease, } \\
\text { years }\end{array}$ & $12.7 \pm 10.8$ & $13.5 \pm 12.5$ & $10.7 \pm 7.9$ & 0.054 \\
\hline $\begin{array}{l}\text { Onset of symptoms, } \\
\text { years }\end{array}$ & $55.6 \pm 12.5$ & $57.5 \pm 13.4$ & $53.3 \pm 10.9$ & 0.017 \\
\hline $\begin{array}{l}\text { Smoking time before } \\
\text { disease, years }\end{array}$ & $29.5 \pm 11.8$ & $30.8 \pm 13.0$ & $28.1 \pm 10.0$ & 0.088 \\
\hline $\begin{array}{l}\text { Pack-year before } \\
\text { disease }\end{array}$ & $34.0 \pm 26.0$ & $33.9 \pm 28.2$ & $34.2 \pm 23.1$ & 0.935 \\
\hline FVC\% predicted & $71.5 \pm 19.4$ & $73.4 \pm 20.1$ & $69.1 \pm 18.1$ & 0.113 \\
\hline $\mathrm{FEV}, \%$ predicted & $43.3 \pm 19.1$ & $39.6 \pm 17.8$ & $46.5 \pm 19.6$ & 0.010 \\
\hline $\mathrm{FEV}_{1} / \mathrm{FVC}$ & $46.7 \pm 11.3$ & $44.4 \pm 11.3$ & $48.5 \pm 11.0$ & 0.009 \\
\hline RV\% predicted & $207.5 \pm 66.7$ & $216.7 \pm 69.2$ & $200.1 \pm 63.9$ & 0.077 \\
\hline $\mathrm{RV} / \mathrm{TLC}$ & $66.0 \pm 10.8$ & $65.0 \pm 11.4$ & $67.4 \pm 10.0$ & 0.117 \\
\hline DLCO \% predicted & $72.9 \pm 45.5$ & $68.0 \pm 27.3$ & $76.9 \pm 55.8$ & 0.163 \\
\hline $\mathrm{R} \%$ predicted & $256.6 \pm 133.0$ & $254.6 \pm 129.4$ & $259.1 \pm 138.0$ & 0.806 \\
\hline $\mathrm{PO}_{2}, \mathrm{mmHg}$ & $81.1 \pm 23.7$ & $81.4 \pm 25.3$ & $80.8 \pm 21.7$ & 0.867 \\
\hline $\mathrm{PCO}_{2}, \mathrm{mmHg}$ & $45.0 \pm 14.2$ & $45.8 \pm 13.8$ & $44.1 \pm 14.6$ & 0.406 \\
\hline
\end{tabular}

Notes: Statistically significant values are shown in bold. Data shown as mean \pm standard deviation.

Abbreviations: DLCO, single-breath diffusing capacity of carbon monoxide; $\mathrm{FEV}_{1}$, forced expiratory volume in one second; FVC, forced vital capacity; $\mathrm{PCO}_{2}$, partial pressure of carbon dioxide; $\mathrm{PO}_{2}$, partial pressure of oxygen; $\mathrm{R}$, airway resistance; $\mathrm{RV}$, residual volume; TLC, total lung capacity. older age when they quit smoking. Death-group patients had lower $\mathrm{FEV}_{1} \%$ predicted and $\mathrm{FEV}_{1} / \mathrm{FVC}$ ratio.

Age (hazard ratio, 1.139; 95\% confidence interval, $1.077-1.204 ; P<0.001)$, age of quitting smoking (1.078; $1.025-1.113 ; 0.003)$, and $\mathrm{FEV}_{1} \%$ predicted $(1.020$; $1.002-1.038 ; 0.025)$ were independently associated with mortality from COPD (Table 2).

The different characteristics of the quitting-smoking group and continuing-smoking group are shown in Table 3. There were no significant differences between them in terms of the amount of smoking, age of onset of smoking, or the number of cigarettes smoked in 1 day. The quitting-smoking group had a lower prevalence of mortality, longer COPD course, earlier onset of COPD symptoms, and lower RV\% predicted than the continuing-smoking group.

Kaplan-Meier survival curves for the quitting-smoking group ( $\mathrm{n}=92 ; 40$ deaths) and the continuing-smoking group $(\mathrm{n}=112 ; 73$ deaths) are shown in Figure 1, and a significant difference between the two groups (log-rank test, 13.59; $P=0.0002)$ was noted. The causes of death of patients with COPD include acute exacerbation of COPD, lung cancer, cardiovascular disease and pulmonary infection (Table 4).

\section{Discussion}

A systematic review and meta-analysis of studies involving COPD carried out in 28 countries during 1990-2004 provided evidence that the prevalence of COPD is appreciably higher in smokers and ex-smokers compared with that in nonsmokers. ${ }^{11}$ In COPD, active cigarette smoking is the most encountered risk factor, and this is associated with accelerated decline in $\mathrm{FEV}_{1}{ }^{12}$ and a higher prevalence of mortality when compared with COPD patients who are nonsmokers. ${ }^{13,14}$ Exposure to cigarette smoking results in an imbalance in levels of matrix metalloproteinases and tissue inhibitors of metalloproteinases, which may lead to insufficient repair of lung tissue; induction of COPD-associated atrophy of skeletal muscle; impaired basal antioxidant defense; and promotion of imbalance between activin-A and follistatin. ${ }^{15-18}$

Death-group patients had a longer smoking time than survival-group patients; smoking time is significantly related to the mortality of patients with COPD. The prevalence of quitters in the survival group $(57.1 \% ; 52 / 91)$ was much higher than that in the death group $(35.4 \%$; 40/113) during 5-year follow-up. A later age at which smoking was quit may lead to some patients having a higher prevalence of mortality. After full adjustment for covariates, the age of quitting smoking (which was one of the most important risk factors influencing the mortality of COPD patients in the death group) was 
Table 2 Variables associated with all-cause mortality of COPD in a Cox proportional hazard regression model

\begin{tabular}{|c|c|c|c|c|}
\hline \multirow[t]{2}{*}{ Variable } & \multicolumn{2}{|l|}{ Unadjusted } & \multicolumn{2}{|l|}{ Fully adjusted } \\
\hline & HR (95\% Cl) & $P$-value & HR $(95 \% \mathrm{Cl})$ & $P$-value \\
\hline Age & $1.093(1.056-1.132)$ & $<0.00 \mathrm{I}$ & $1.139(1.077-1.204)$ & $<0.001$ \\
\hline Years of smoking & 1.043 (I.0I5-I.07I) & 0.002 & $0.984(0.950-1.020)$ & 0.389 \\
\hline Age of quitting smoking & 1.091 (1.057-I.126) & $<0.00 \mathrm{I}$ & $1.078(1.025-1.113)$ & 0.003 \\
\hline Onset of symptoms & $1.036(1.011-1.062)$ & 0.005 & $0.975(0.940-1.011)$ & 0.166 \\
\hline FEV $\%$ predicted & $1.020(1.004-1.036)$ & 0.028 & $1.020(1.002-1.038)$ & 0.025 \\
\hline
\end{tabular}

Note: Statistically significant values are shown in bold.

Abbreviations: $\mathrm{Cl}$, confidence interval; $\mathrm{FEV}_{\text {, }}$, forced expiratory volume in one second; HR, Hazard ratio.

1.078-times that documented in survival-group patients, and was independent of other variables. Quitting smoking can slow lung function decline, decrease the symptoms and the number of exacerbations, and prolong survival time of patients.

Older age has been identified as a risk factor associated with a higher prevalence of mortality in COPD patients. . $^{1920}$ Age (hazard ratio, 1.139; 95\% confidence interval,

Table 3 Differences in clinical characteristics between patients of smoking-cessation group and continuing-smoking group

\begin{tabular}{|c|c|c|c|c|}
\hline Parameter & $\begin{array}{l}\text { Both } \\
\text { groups }\end{array}$ & $\begin{array}{l}\text { Quitting } \\
\text { smoking }\end{array}$ & $\begin{array}{l}\text { Continuing } \\
\text { smoking }\end{array}$ & $P$-value \\
\hline Subjects, $\mathrm{n}$ & 204 & 92 & 112 & \\
\hline $\operatorname{Sex}(M / F), n$ & $201 / 3$ & $90 / 2$ & $|I| / \mid$ & 0.452 \\
\hline Age, years & $67.9 \pm 9.4$ & $68.4 \pm 9.3$ & $67.4 \pm 9.4$ & 0.425 \\
\hline $\begin{array}{l}\text { Age of quitting } \\
\text { smoking, years }\end{array}$ & & $58.8 \pm 10.4$ & & \\
\hline Pack-year & $45.3 \pm 34.5$ & $44.6 \pm 29.4$ & $45.9 \pm 38.3$ & 0.791 \\
\hline $\begin{array}{l}\text { Years of smoking, } \\
\text { years }\end{array}$ & $38.2 \pm 11.5$ & $35.5 \pm 10.8$ & $41.6 \pm 11.6$ & 0.001 \\
\hline $\begin{array}{l}\text { Cigarettes smoked } \\
\text { in I day, n }\end{array}$ & $23.0 \pm 13.0$ & $23.9 \pm 11.9$ & $22.2 \pm 13.8$ & 0.353 \\
\hline $\begin{array}{l}\text { Age of onset of } \\
\text { smoking, years }\end{array}$ & $25.9 \pm 8.3$ & $25.1 \pm 8.2$ & $26.8 \pm 8.2$ & 0.131 \\
\hline Death & 113 & 40 & 73 & 0.002 \\
\hline $\begin{array}{l}\text { Exacerbations in } \\
\text { past } 12 \text { months }\end{array}$ & $1.3 \pm 1.4$ & $1.1 \pm 1.9$ & $1.2 \pm 1.7$ & 0.286 \\
\hline $\begin{array}{l}\text { Course of disease, } \\
\text { years }\end{array}$ & $12.7 \pm 10.8$ & $13.9 \pm 10.5$ & $10.8 \pm 10.9$ & 0.040 \\
\hline $\begin{array}{l}\text { Onset of } \\
\text { symptoms, years }\end{array}$ & $55.6 \pm 12.5$ & $54.4 \pm 10.8$ & $57.5 \pm 10.9$ & 0.043 \\
\hline FVC\% predicted & $71.5 \pm 19.4$ & $73.1 \pm 19.7$ & $70.2 \pm 19.1$ & 0.290 \\
\hline $\mathrm{FEV}, \%$ predicted & $43.3 \pm 19.1$ & $44.5 \pm 19.3$ & $42.6 \pm 19.0$ & 0.486 \\
\hline $\mathrm{FEV}_{1} / \mathrm{FVC}$ & $46.7 \pm 11.3$ & $46.8 \pm 10.5$ & $46.6 \pm 12.0$ & 0.895 \\
\hline RV\% predicted & $207.5 \pm 66.7$ & $197.3 \pm 54.7$ & $215.9 \pm 74.2$ & 0.041 \\
\hline $\mathrm{RV} / \mathrm{TLC}$ & $66.0 \pm 10.8$ & $65.1 \pm 10.0$ & $66.8 \pm 11.5$ & 0.272 \\
\hline DLCO \% predicted & $72.9 \pm 45.5$ & $69.3 \pm 27.1$ & $75.9 \pm 56.2$ & 0.307 \\
\hline $\mathrm{R} \%$ predicted & $256.6 \pm 133.0$ & $255.3 \pm 126.5$ & $257.7 \pm 138.6$ & 0.897 \\
\hline $\mathrm{PO}_{2}, \mathrm{mmHg}$ & $81.1 \pm 23.7$ & $81.2 \pm 24.3$ & $81.1 \pm 23.3$ & 0.983 \\
\hline $\mathrm{PCO}_{2}, \mathrm{mmHg}$ & $45.0 \pm 14.2$ & $44.8 \pm 13.3$ & $45.2 \pm 14.9$ & 0.812 \\
\hline
\end{tabular}

Notes: Statistically significant values are shown in bold. Data shown as mean \pm standard deviation.

Abbreviations: DLCO, single-breath diffusing capacity of carbon monoxide; $\mathrm{FEV}_{1}$, forced expiratory volume in one second; FVC, forced vital capacity; $\mathrm{PCO}_{2}$, partial pressure of carbon dioxide; $\mathrm{PO}_{2}$, partial pressure of oxygen; $\mathrm{R}$, airway resistance; $\mathrm{RV}$, residual volume; TLC, total lung capacity.
1.077-1.204; $P<0.001$ ) was independently associated with mortality from COPD. Many COPD patients simultaneously suffer from malignant tumor, cardiovascular disease, and other system diseases related to smoking, and these further affect the patients' prognosis and survival time. But the causes of death were consistent between smokingcessation group and continuing-smoking group. According to Menezes et al, ${ }^{21}$ a low $\mathrm{FEV}_{1}$ is a risk for overall and respiratory mortality. $\mathrm{FEV}_{1} \%$ predicted was used to assess $\mathrm{COPD}$ severity but was also independently associated with mortality from COPD. Smoking leads to increase in airway resistance and alveolar damage and $\mathrm{FEV}_{1}$ decline, promoting dyspnea, hypoxemia, and carbon dioxide retention. Respiratory failure further aggravates cardiovascular disease and pulmonary hypertension. Respiratory failure and heart failure are the immediate death causes of patients with COPD. The FEV value of patients in the death group was much less than that in the survival group, as can be seen from Table 1. The smoking times and time of onset of COPD symptoms were also important factors influencing mortality from COPD, but were not independent factors.

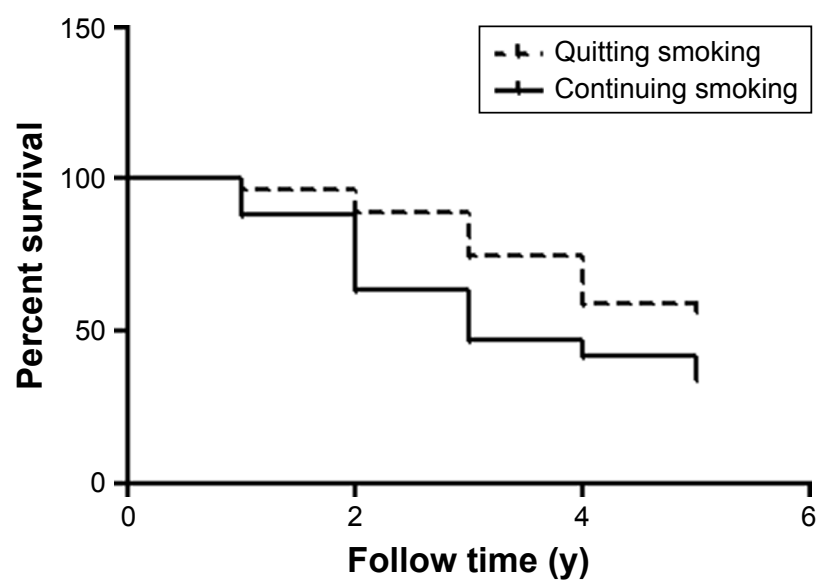

Figure I Kaplan-Meier survival curves for COPD patients in the quitting-smoking group ( $\mathrm{n}=92 ; 40$ deaths) and continuing-smoking group ( $\mathrm{n}=112 ; 73$ deaths).

Notes: Patients in the quitting-smoking group had lower survival than those in the continuing-smoking group. There was a significant difference between the two groups (log-rank test, I 3.59; $P=0.0002$ ). 
Table 4 Causes of patient death in smoking-cessation group and continuing-smoking group

\begin{tabular}{|c|c|c|c|c|}
\hline Causes of death & $\begin{array}{l}\text { Both } \\
\text { groups, } \\
\text { n }\end{array}$ & $\begin{array}{l}\text { Quitting } \\
\text { smoking, } \\
\text { n (\%) }\end{array}$ & $\begin{array}{l}\text { Continuing } \\
\text { smoking, } \\
\text { n (\%) }\end{array}$ & $P$-value \\
\hline AECOPD & 60 & $21(52.5)$ & $39(53.4)$ & 0.926 \\
\hline Cardiovascular disease & 17 & $6(15)$ & II (I5.I) & 0.992 \\
\hline Lung cancer & 15 & $6(15)$ & $9(12.3)$ & 0.692 \\
\hline Pulmonary infection & 9 & $3(7.5)$ & $6(8.2)$ & 0.894 \\
\hline Other diseases & 12 & $4(10)$ & $8(11.0)$ & 0.876 \\
\hline Total & 113 & 40 & 73 & 0.002 \\
\hline
\end{tabular}

Note: Statistically significant values are shown in bold.

Abbreviation: AECOPD, acute exacerbation Chronic Obstructive Pulmonary Disease.

The prevalence of mortality in COPD patients has been reported to be significantly higher among nonquitters compared with that in quitters. ${ }^{22,23}$ Most studies have suggested that quitting smoking is beneficial for COPD patients compared with continued smoking and that it improves survival compared with continued smoking. ${ }^{23,24}$ During 5-year follow-up, 113 patient deaths were recorded (quittingsmoking group: $\mathrm{n}=92 ; 40$ deaths; continuing-smoking group: $\mathrm{n}=112 ; 73$ deaths), and the risk remained significantly higher in the continuing-smoking group compared with the quitting-smoking group (log-rank test, 13.59; $P=0.0002$ ). In the present study, the quitters had lower RV\% predicted than nonquitters, which suggests that quitting smoking would relieve pulmonary emphysema to some degree and be beneficial for COPD patients. The quitters had an earlier age of onset of COPD symptoms and longer course of disease. The COPD patient with early onset of symptoms may have quit smoking in younger age, and this phenomenon would be likely to result in the course of COPD being lengthened. Hence, quitting smoking has the greatest capacity to influence the natural history of COPD.

\section{Limitations}

The main limitation of our study was that it was retrospective. In addition, the number of patients was not large. However, this study assessed real-world data for 5 years, and the results have considerable clinical value. A similar prospective study with a larger sample should be conducted in the future.

\section{Conclusion}

Death-group patients had a longer smoking time, a lower prevalence of quitting smoking, later onset of COPD symptoms, an older age of quitting smoking, and lower $\mathrm{FEV}_{1} \%$ predicted and $\mathrm{FEV}_{1} / \mathrm{FVC}$ ratio. Age, the age of quitting smoking, and $\mathrm{FEV}_{1} \%$ predicted were independently associated with mortality from COPD. Smoking time may be related to the mortality of COPD patients according to the quantitative indicators of smoking. The quitting-smoking group had a lower mortality rate, longer course of COPD, earlier onset of COPD symptoms, and lower RV\% predicted. Smoking cessation has the greatest capacity to influence the natural history of COPD.

\section{Author contributions}

All authors contributed toward data analysis, drafting and critically revising the paper, gave final approval of the version to be published, and agree to be accountable for all aspects of the work.

\section{Disclosure}

The authors report no conflicts of interest in this work.

\section{References}

1. Global Strategy for the Diagnosis, Management and Prevention of COPD Available from: http://goldcopd.org/wp-content/uploads/2016/12/ wms-GOLD-2017-Pocket-Guide.pdf. Accessed March 9, 2017.

2. Eisner MD, Anthonisen N, Coultas D, et al. An official American Thoracic Society public policy statement: novel risk factors and the global burden of chronic obstructive pulmonary disease. Am J Respir Crit Care Med. 2010;182(5):693-718.

3. Rabe KF, Hurd S, Anzueto A, et al. Global Initiative for Chronic Obstructive Lung Disease. Global strategy for the diagnosis, management, and prevention of chronic obstructive pulmonary disease: GOLD executive summary. Am J Respir Crit Care Med. 2007;176(6):532-555.

4. Zhong N, Wang C, Yao W, et al. Prevalence of chronic obstructive pulmonary disease in China: a large, population based survey. Am J Respir Crit Care Mcd. 2007;176(8):753-760.

5. van der Toorn M, Smit-de Vries MP, Slebos DJ, et al. Cigarette smoke irreversibly modifies glutathione in airway epithelial cells. Am J Physiol Lung Cell Mol Physiol. 2007;293(5):L1156-L1162.

6. van der Toorn M, Rezayat D, Kauffman HF, et al. Lipid-soluble components in cigarette smoke induce mitochondrial production of reactive oxygen species in lung epithelial cells. Am J Physiol Lung Cell Mol Physiol. 2009;297(1):L109-L114.

7. Angelis N, Porpodis K, Zarogoulidis P, et al. Airway inflammation in chronic obstructive pulmonary disease. J Thorac Dis. 2014;6(Suppl 1): S167-S172.

8. Bagdonas E, Raudoniute J, Bruzauskaite I, Aldonyte R. Novel aspects of pathogenesis and regeneration mechanisms in COPD. Int $J$ Chron Obstruct Pulmon Dis. 2015;10:995-1013.

9. Fischer BM, Voynow JA, Ghio AJ. COPD: balancing oxidants and antioxidants. Int J Chron Obstruct Pulmon Dis. 2015;10:261-276.

10. Silva R, Oyarzún M, Olloquequi J. Pathogenic mechanisms in chronic obstructive pulmonary disease due to biomass smoke exposure. Arch Bronconeumol. 2015;51(6):285-292.

11. Halbert RJ, Natoli JL, Gano A, Badamgarav E, Buist AS, Mannino DM. Global burden of COPD: systematic review and meta-analysis. Eur Respir J. 2006;28(3):523-532.

12. Anthonisen NR, Skeans MA, Wise RA, et al. The effects of a smoking cessation intervention on 14.5-year mortality: a randomized clinical trial. Ann Intern Med. 2005;142(4):233-239.

13. Henley SJ, Thun MJ, Chao A, Calle EE. Association between exclusive pipe smoking and mortality from cancer and other diseases. $J$ Natl Cancer Inst. 2004;96(11):853-861. 
14. Rodriguez J, Jiang R, Johnson WC, MacKenzie BA, Smith LJ, Barr RG. The association of pipe and cigar use with cotinine levels, lung function, and airflow obstruction: a cross-sectional study. Ann Intern Med. 2010;152(4):201-210.

15. Sun J, Bao J, Shi Y, et al. Effect of simvastatin on MMPs and TIMPs in cigarette smoke-induced rat COPD model. Int J Chron Obstruct Pulmon Dis. 2017;12:717-724.

16. Ma R, Gong X, Jiang H, et al. Reduced nuclear translocation of serum response factor is associated with skeletal muscle atrophy in a cigarette smoke-induced mouse model of COPD. Int J Chron Obstruct Pulmon Dis. 2017;12:581-587.

17. Dove RE, Leong-Smith P, Roos-Engstrand E, et al. Cigarette smokeinduced induction of antioxidant enzyme activities in airway leukocytes is absent in active smokers with COPD. Eur Clin Respir J. 2015;2(1):27837.

18. Verhamme FM, Bracke KR, Amatngalim GD, et al. Role of activin-A in cigarette smoke-induced inflammation and COPD. Eur Respir J. 2014;43(4):1028-1041.
19. Groenewegen KH, Schols AM, Wouters EF. Mortality and mortalityrelated factors after hospitalization for acute exacerbation of COPD. Chest. 2003;124(2):459-467.

20. Bai JW, Mao B, Yang WL, Liang S, Lu HW, Xu JF. Asthma-COPD overlap syndrome showed more exacerbations however lower mortality than COPD. QJM. 2017;110(7):431-436.

21. Menezes AM, Pérez-Padilla R, Wehrmeister FC, et al. FEV1 is a better predictor of mortality than FVC: the PLATINO cohort study. PLoS One. 2014;9(10):e109732.

22. Kupiainen H, Kinnula VL, Lindqvist A, et al. Successful smoking cessation in COPD: association with comorbidities and mortality. Pulm Med. 2012;2012:725024.

23. Godtfredsen NS, Lam TH, Hansel TT, et al. COPD-related morbidity and mortality after smoking cessation: status of the evidence. Eur Respir J. 2008;32(4):844-853.

24. Zamarro García C, Bernabé Barrios MJ, Santamaría Rodríguez B, Rodríguez Hermosa JL. Smoking in COPD. Arch Bronconeumol. 2011; 47 (Suppl 8):3-9.

\section{Publish your work in this journal}

The International Journal of COPD is an international, peer-reviewed journal of therapeutics and pharmacology focusing on concise rapid reporting of clinical studies and reviews in COPD. Special focus is given to the pathophysiological processes underlying the disease, intervention programs, patient focused education, and self management protocols.

\section{Dovepress}

This journal is indexed on PubMed Central, MedLine and CAS. The manuscript management system is completely online and includes a very quick and fair peer-review system, which is all easy to use. Visit http://www.dovepress.com/testimonials.php to read real quotes from published authors. 